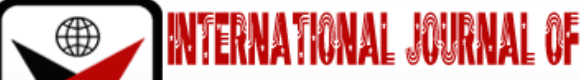 \\ בmRक
}

ISSN 2278-0211 (Online)

\section{Corporate Sociall Responsibility and Sustainable Development in Marketing Environment: A Conceptual Review}

Dr. Mairo Abdullahi
Senior lecturer, Department of Business Administration
Usmanu Danfodiyo University Sokoto Nigeria
Dr. Sadat Ibn Adam
Senior lecturer, Department of Business Administration
Usmanu Danfodiyo University Sokoto Nigeria

\begin{abstract}
s:
The objective of the study is to review the concepts of corporate social responsibility within the marketing environment of the $21^{\text {st }}$ century for sustainability. A corporation that is socially responsible will exhibit commitment to ethical behavior, it also contributes to the economic development, hence it provides good quality of life for the employees and their families, as well as, their immediate and extended environment at large. Sustainable development can be seen as the adoption of some marketing activities and business strategies today, that meet the desire of the customers and stakeholders of the enterprise, while sustaining, protecting, natural and human resources enhancement for future generation. Environment of marketing is the physical, operational, internal, externaletc. which affect business activities. They include; customers, competitors, suppliers/ distributors, political activities, economic, demographics, social and cultural activities, as well as technological innovations. However, the effect of corporate social responsibility and sustainable development in marketing environment cannot be over emphasize, because in the global arena of today, the interconnectivity between investors, creditors and other stakeholders cannot be overemphasize. It has come to lime light that environmental, social, and governance of an organization are vital parts of its sustainability and long-term performance. These concerns are the major determinant of corporate profitability. The marketing environment has a greater influence on organizations and the success of any business is dependent on its ability to adapt to its environment.
\end{abstract}

Keywords: Corporate Social Responsibility, Sustainable Development, Marketing Environment, stakeholders and consumers

\section{Introduction}

In the mid-1970s up to the 1900s active environmental movement has been established, but experts warned that the planet's natural systems were being distorted by human industrial activities (World Watch, 2000). Scientists and experts gave serious warning about the danger in burning of forest that is known as 'fossil fuel' that threatens the health of all living things within the planet (Mintu et al., 1993). The global environmental and the living condition of inhabitants have to a large extend continue to deteriorate, which cans makes the concern of scientist and experts valid and genuine. Over 50,000 species of living and nonliving things have become extinct. Hence,8.2 billion tons of polluting carbon dioxide are dumped into the atmosphere, while the forest was said to have disappear by 17 million hectares. 6.5 million tons of refuse were said to be dumped in the world's seas, killing seabirds and fish. Furthermore, annually the population of the worldhas reached 100 million people (United Nations Chronicle, 1992), by implication no serious action has been taken on environmental decadence.

Marketing importance cannot be over emphasized in environmental solutions of today, just like any other business functional area. Marketing, has a role to play toward providing solutions, to environmental problems (Polonsky et al., 1997). Indeed, Green Marketing was brought about by good marketing. However, firms all over the world are finding it difficult to adopt to the new role, of meeting the needs and wants of the present generation, without due consideration of the future generation's needs. Corporate managers must be responsibility for the ways their operations impact natural environment and societies at large. Sustainability principles must be adhered to by management of companies. Corporations must not experience economic prosperity in isolation by implication, the impact of economic prosperity should be felt across the society positively. Business entities should focus attention on both increasing profitability and being good corporate citizen. Firms should keep abreast of global trends and remain committed to financial obligations to deliver both private and public benefits. These have forced organizations to reshape their frameworks, rules, and business models. The most socially responsible organization should as a matter of fact continue to strategize and re-strategize to stay ahead of rapidly changing environmental challenges. 
The aim of the study therefore, is to conceptualize how CSR and SDaffect the marketing environment. The study also addresses issues in areas of CSR, SD within the context of marketing environment. Discussions also capture the effect of CSR and SD in marketing environment. Lastly, the researcher concludesthe concepts of CSR and SD have to be dynamic with changing times and marketing environment, in order to suit the practical realities obtainable in different parts of the world.

\section{Conceptual Review of Corporate Social Responsibility (CSR), Sustainable Development (SD) and Marketing Environment (ME)}

\subsection{Corporate Social Responsibility (CSR)}

CSR has been given various names, among which responsible entrepreneurship, stewardship or corporate citizenship, corporate responsibility, corporate accountability, corporate ethics and triple bottom line, to mention but a few.CSR issues have become integrated increasingly into latest organizational practices, to this effect it is also refers to as 'responsible competitiveness' or 'corporate sustainability. 'Notably the CSR concept is an evolving one, it does not have a definitionthat is universally accepted currently. CSR can be broadly viewed as the ways firms incorporate economic, social and environmental concerns into their culture, decision making, values, operation and strategy in a transparent and accountable manner. Hence, the establishment of better practices within the firm, improve society and create wealth.

According to McWilliams and Siegel (2001), posits that, CSR can be conceptualized as the positive actions that produces positive outcome above the firm's interest, but maintain its action within the stipulated arms of the law. Bowen (1953) found out the modern concept definition as early as 1953, he recommends that, businesses are responsible for their actions beyond just declaring profit and loss statements. The scholarly researches of Carroll's (1979)Konrad et al., (2006)evolved from the fact that a socially responsible organization comprises of the political, legal, economical, ethical, cultural expectations that society has for organizational behavior. Hence, there is consensus of opinion by scholars on its wider definition, hence, businesses now make attempts to incorporate CSR projects in to the culture of the organization permanently. However, the satisfaction derived from the consumers, businesses and governmental organizations are increasing as a result of CSR prosits.CSR can be integrated in to business models, that encompasses; social performance, corporate conscience, citizenship and sustainable responsible business in the form of corporate self-regulation. CSR has incorporated the policy functions of regulating itself, which involves business monitoring itself and ensures its active compliance with the spirit of the law, ethical standards, and international norms in-built in it (Fontaine, 2013).

According to Ivancevich, Lorenzi, Skinner and Crosby (1997), 0rganizations that are socially responsible, pursues profit only within the confines of the law. Businesses are expected to repay society by making profits, hence societies support businesses by allowing it to exit through patronizing the goods and services produced by it. Thus, in view of the above scholars, socially responsible organizational behavior, could be seen as that behavior that is legal or is in pursuit of profit. In addition, socially responsible behaviors are anticipatory and preventative, rather than reactive and restorative. The term social responsiveness has become widely used in recent years to refer to actions that exceed social obligation and social reaction. A socially responsive corporation actively seeks solutions to social problems. According to Friedman (1970) society creates firms to pursue two primary purposes to satisfy needs and wants of consumer and hence for the production of goods, services and maximization of profits.

Mahajan (2011) analyses that, an approach to CSR that has become more widely accepted is the community-based approach. In this approach, corporations work with local communities to better themselves. Philanthropy, is another approach, this is said to be monetary donations and donations in form of aids given to impoverished communities and local organizations in developing countries. Another approach to CSR is to incorporate the CSR strategy directly into the business strategy of an organization. Fioravante (2010) noted with considerable interest that, the most essential factor in strategic marketing planning for a firm to explore both internal and external means of survival. Hence, corporate philanthropy has become an important marketing strategic option in the development of organizational strategies. Firms that engage in brand development, market recognition, and enhanced customer perceptions can incorporate philanthropic initiatives throughout the planning process. Implementing these initiatives leads to the creation of a distinctive competitive advantage. This phenomenon in marketing provides a vital economic and social approach to fasttrackbusiness agendas necessary for market sustainability.

To ascertain how CSR is implemented in organizations, some research D'Amata, Hinderson \& Florence (2009)uses a framework that is developmental, to show changes in strategy, awareness and action over time. CSR from elementary to transformation as contended by the above scholars is as follows; 1) Drivers of Ongoing Commitment; this can be derived from ethical or economic background. Oftentimes, both of these apply, when the value added is considered to be significant and positive. Building the business to conform with CSR, Husted and Allen (2007) point out that positive CSR can be linked to improved financial performance. Therefore, it makes sense to say that looking after the people and the community as well as the environment is all relevant to long-term business survival. In a business arena, CSR appears stronger, but in literature there is reflection of doubts and as well as criticisms (Jayne, 2004).2) Corporate Identity and Ethics; this reflects what a company really is, rather than what a company might advocate. Many companies have used corporate identity in branding themselves, which has become a turning point for success and competitive advantage (Werther \& Chandler, 2006). 3) CSR and Accountability; here an organization seeks to ensure integrity through the process of accountability. Accountability is among the key challenges of organizations especially in a stakeholder's society. Responsible organizations are concerned with aligning and reconciling of needs, wants, interests, demand and values of employees, customers, suppliers, communities, shareholders, NGOs, the environment, and largersociety. The track record of an organization in terms of CSR accounting will be effective when appropriate CSR measures are included in its internal as well as its supply- 
chain activities. Furthermore, organizations need to improve in the dissemination of ethical behavior like prudence and accountability in handling and producing their services to humanity (Frame, 2005). 4) Partnering with Stakeholders; CSR is strictly embedded with a multitude of business actors. With sustainability calls, changing business roles, increased expectations and new rules and tactics (Burke, 2005). Organizations are bound to come into contact and conflict with key stakeholders in their quest for responsible business. This ranges from global to regional, local to national up to international, cultural variations should be envisaged. The concept of stakeholder engagement and communication with stakeholders must be in the leadership practices for CSR.

\subsection{Sustainable Development (SD)}

The growing concern for environment, resources and social equity in the 1980s led to the emergence of the definition of Sustainable Development (SD), which was defined as 'development that meets the present needs of the people without comprising the future needs of generations yet unborn, according to Brundtl and Report. Although many definitions abound, the most often used definition of SD is the one proposed by the Brundtland Commission. Itwas propounded as, all resources that can be managed economically, socially, and aesthetical needs can be fulfilled through an infinite period of time. This can be achieved through accountability, maintaining cultural integrity, essential ecological processes, biological diversity, and life support systems' (Inskeep, 1998).

However, Cerin (2006), Dernbach (1998),Dernbach (2003) and Stoddart (2011), unanimously concurred with those touches on the importance of intergenerational equity. The concept of SD has received growing recognition, many business executives, see it as a new concept. For most, the concept remains in theory. Organizations most protect its capital base in a well-accepted business principle. Organizations most recognize the possibility of extending this notion to the world's natural and human resources. If SD is to be achieved, it must be integrated intoorganization's planning and measurement systems. And for that to happen, the concept must be simplified to meet the best understanding of business leaders. The concept also captures business's dependence on human and natural resources, in addition to physical and financial capital. Impliedly, the economic activity must not have an advice effect on the human and natural resources. This definition intends to help business owners apply the definition of SD, in to the organizational rules and regulations. However, it is vital to note that SD cannot be achieved by a single enterprise in isolation, it is a pervasive philosophy that incorporate all the stake holders in the global world, to subscribe in to. Hence, there is the need to meet today's wants without compromising the ability of future generations to meet their own needs and wants.

Holmberg (1992) Reed (1997) and Harris et al., (2001) enumerate three essential aspects of sustainable development, which include; The economic, ecological and the social perspective. The social perspective recognizes the social component of development as very essential part of 'human development' Human development approach emphasizes on issues of basic needs and equity is well grounded in the history of economic theory. Anand and Sen (1996) confirm that, modern economist have dominated human development approaches to the wealth maximization approach.

Among the principles of S Dare: Sustainable economic production and intergenerational equity depends on the conservation of capital. Market mechanisms may not work perfectly on the issue of conserving natural capital, but may tend to deplete and degrade it, from an ecological perspective. Ecosystems and diversity of species must be maintained and integrated; both population and total resource demand must be limited. Practices consistent with SD must result in environmental damage and social inequities, while maintaining a sound economic base. Social equity, could be the fulfillment of basic health and educational needs, and participatory democracy are crucial elements of development. These are also part and parcel of environmental sustainability. All these principles clearly suggest new guidelines for the development process and a modification on the economic growth goals (Arrow et al., 1995). The principles of SD evolved with new goals and policies in all major areas of economic development, including Population. Resource and environmental constraints will eventually be reached, even if human capacity is unidentified a sustainable society means stable level of population, by population policy the society must become a central element of economic development. Scherr (1997) suggests social equity and women's right most be maintained in order to achieve slow rate of population growth in the developing world. Global sustainable development challenges, have been dated back to 2000, United Nations Millennium Declaration was adopted by world leaders, which provided the basis for the Millennium Development Goals to be reached. Poverty reduction and human development forma successful global consensus. Since then, a large segment of the world population that were faced with numerous challenges were uplifted by the global community. On record, more than 1 billion people are still living in extreme income inequality, poverty, unsustainable consumption and production patterns have resulted in huge environmental, economic and social endangerment of lives. People living below poverty line of less than $\$ 1.25$ a day fell from, 47 per cent in 1990 to 22 per cent in 2010 . In 2010 about 700 millionpeople lived in conditions of extreme poverty. Internationally, results fail short of expectation of the global targets set to be reached by the 2015 deadline. The achievement of Millennium Development Goal will remain imperative, if the international community did not take bold and collaborative actions to accelerate progress.

Achievement of SD may not be possible if current development strategies most continue in that way, hence evidence is mounting that: climate change is impacting negatively on our planet. Secondly, Hunger and malnourishment, are decreasing in many developed countries, but remain persistent in underdeveloped and developing nations, where food and nutrition security diminishes continuously for many countries. Thirdly, income inequality is on the rise within many countries it has reached an extremely high level, invoking tension and social conflict. Fourthly, urbanization, especially in underdeveloped and developing countries, calls for major changes in the way in which urban development is designed and managed. Energy needs are likely to remain unmet for hundreds of millions of households, unless significant progress in ensuring access to modern energy services is achieved. Lastly, financial system has to be redirected for the prevention of financial crises and promoting long term financings for investment purposes. 


\subsection{Marketing Environment}

No business operates in a vacuum. Decisions are made within the context of customer characteristics, competition, suppliers/distributors, legislative and social framework (Kotler, 2016). People working within organizations contributes to their welfare and that of the society at large. Better standard of living is obtained through the complex network of exchange. In marketing, managing the exchange process between organization and its customers is very vital, considerations should be accorded tothe effects of customer-based decisions on people and organizations (Kotler, 2005). Stakeholders are individuals or organizations that have direct or indirect input in to marketing decisions, which could be; neighbors, suppliers, competitors, customers, or governments. Some marketing environmental factors can be controlled by managers, whereas others cannot be controlled, hence such uncontrollable environmental factors must therefore be accommodated in decision-making. Furthermore, larger firm have greater control over their environment. By implication, larger organizations find it difficult to adapt to sudden environmental changes, unlike smaller ones. The impact of different environmental factors can be evaluated as follows;

Marketing environmental factors can be classified in a number of ways. Firstly, the environment can be classified in terms of those elements that affect organizations within the industry(the macro environment) and secondly, those elements that affect only the individual firm (the micro environment). The macro environment can be explained through; the economy, socio-cultural, natural, political, technological etc. These can be difficult to influence or control, whereas the micro environment, is much more within the firm's control. Internal or external factor are among the classification of marketing environment. The internal environment comprises of those factors that operate within the firm (the corporate culture and history, staff behavior and attitudes, the firm's capabilities) and the external environment comprises those elements that operate outside the firm(competition, government, customers, Suppliers, marketing intermediaries etc.). An organization must be able to determine where the boundaries lie: for a truly customer-orientated company, customers might be considered as part of the internal environment. In effect, the firm operates within a series of layers of environmental factors, each of which has a greater or lesser impact on the firm's marketing policies. As a general rule, the further out the layer is, the more difficult it is for the firm to control what is happening: only the very largest firms have control, or even influence, on the macro environment (Smith, 1998)

\subsection{The Effect of CSR and SD on the Marketing Environment}

CRS and SD form an integral part of the business and society literature; it addresses topics of ethical behavior in business, CSR performance, global corporate citizenship, and stakeholder management among others. CRS and SD emanated from management education. Management education can be an important source of new ideas of understanding the relationship between variables in the society. It is also about shifting toward an integrated rather than fractured knowledge economy. Management education also means that, the role and meaning of socially responsible leadership needs to be updated. However, globalization has brought interconnectivity of numerous factors, to the extent that, world investors, creditors and other stakeholders have come to recognize that environmental, social, and governance responsibilities of a company are integral to its performance and long-term sustainability.For companies to operate successfully and sustain growth, boards must incorporate these new dimensions into their core decision making processes in other to determine long term profitability.

The global financial crisis has brought to lime light the need for corporate boards of directors to provide wellinformed strategic direction and engaged oversight functions to staff, that stretches beyond short-termperformance of the organization. In doing so, companies comprehensively learned in the act of addressingrisks, anticipating potentially adverse impacts on stakeholders and risks management as well. Wealth generation can also be creating shareholder value through an increase in business opportunities and broader access to markets. Businesses are coming up with new visions and missions in their organizations, where a set of core values, encompassing; human rights, environmental protection and anti-corruption measures, relationship with management, and accountability to shareowners, guide the broad decisions of management.

However, the understanding of CSR and SD in a marketing environment has changed immensely since the 1950s. Those concepts were understood in a way that businesses had economic and legal obligations towards shareholders and to some extent a responsibility towards society, which was interpreted differently from company to company. (Carroll, 1999) Over the years, companies have recognized that, CSR should be part and parcel of their actions, which has developed into having an effect on stakeholders, the environment and society. In its wake, companies have begun to publish reports which tend to be about general commitments to society or the environment, instead of actual performance. Another common approach is philanthropy in form of donations to local or international organizations. Many companies see those terms is an easy way to improve sales, enhancing a company's image and attracting investors. (Kotler \& Lee 2005) and Emery (2012). However, Emery (2012) posits that, those approaches are often end-of-pipe solutions instead of changing processes within the company. Overall, they have to be practiced carefully. If a company lets everybody know about their CSR, SD efforts, accusations of only doing it for image purposes, are never far behind. A CSR,SD strategy has to be built individually by each company, depending on the most pressing environmental and social issues for the business.

\section{Conclusion}

It has become a known fact that environmental problems are substantial, and that economic growth contributes to them. In response to that, strict environmental regulation, which often inhibits growth need to be in place. They result in to a healthy environment and healthy organizational growth. As a consequence of that, business opportunities will be highly obtained within that environment. Hence, there are some forms of development that are both environmentally and socially sustainable. They lead to an improved environment, together with development that does not draw down on our 
environmental capital, which leads to sustainability. Revolutionary changes in the way we approach these issues are very necessary. Businesses and societies can find approaches that will move towards the achievement of environmental protection, social wellbeing and economic development for sustainability. Sustainable development is good business in itself, because it offers greater opportunities for suppliers of 'green consumers'. Theyare developers of environmentally safer materials and processes, firms that invest in eco-efficiency, and engage themselves in social well-being. These enterprises will have an edge over and above competitors. Firm that practices CRS, SD in a suitable marketing environment will earn their local community's goodwill and see their efforts reflected in the bottom line. Organizations must seek precision and practicality as the basis for its planning efforts. it is paramount for organizations to note that SD is a concept that is not amenable to simple and universal definition. It changes over time in response to increased information and society's evolving priorities.

From a broader perspective, it is clearly in the interest of business to operate within a healthy environment and economy. It is a fact that, growing and sustainable economies in the under developed and developing countries will provide the best opportunities for expanding markets globally. To some, SD and environmental stewardship are synonymous. Sound environmental performance is probably a reasonable objective for most businesses within short term. CRS and SD are seen as longer-term goals for many businesses. However, this can lead to confusion. In the developed world, the focus is on environmental management, while in underdeveloped and developing countries, CRS and SD is very vital component. The global economy is coming under growing pressure to pay for the restoration of damaged environments. But this economic engine is being asked to help solve other pressing problems at the same time. The challenge is to solve all of these problems in a sustainable manner, so as to generate continuing development. Despite ambiguities about definitions, there is now widespread support for CRS and SD principles within the business community. However, for that support to grow it will be important to recognize and reward initiatives that are being taken to turn the concept into reality.

\section{References}

i. Anand, S and Sen, K (1996), Sustainable Human Development: Concepts and Priorities, United Nations Development Programme, Office of Development Studies Discussion Paper Series.

ii. Arrow, K., Christophersen, C., Jakubik, P., Carlos, E and Echikas, L. (1995), 'Economic Growth, Carrying Capacity, and the Environment', Science,268, 520-521.

iii. Bowen, E. (1953). A Strategic posture towards corporate social responsibility, California Management Review, 18, 49-58.

iv. Burke, R.C. (2005) 'Major issues in Tourism Ecolabelling' in Font, X. and Buckley, R.C. (ed.) Tourism Ecolabelling - Certification and Promotion of Sustainable Management, Wallingford: Cabi.

v. Carroll, B. (1979). Sustainable development strategies: Tools for policy coherence. Natural Resources Forum, 136-145.

vi. Carroll, B. (1999) 'Corporate Social Responsibility - Evolution of a Definitional Construct', Business Society, vol. 38, no. 3, pp. 268-295.

vii. Cerin, P. (2006). Bringing economic opportunity into line with environmental influence: A Discussion on the Coarse theorem and the Porter and van der Linde hypothesis. Ecological Economics, 209-225.

viii. Common, M., and Perrings, C., (1992) 'Towards an Ecological Economics of Sustainability', Ecological Economics6, 7-34.

ix. D'amato,A. Henderson, S. and Florence, S.(2009) Corporate Social Responsibility and Sustainable Business: A guide to leadership Tasks and Function. Center for Creative Leadership Greens bore, North Carolina. ISBN: 9781-60491-063-6

x. Dernbach, J. C. (1998). Sustainable development as a framework for national governance. Case Western Reserve Law Review, 1-103.

xi. Dernbach, J. C. (2003). Achieving sustainable development: The Centrality and multiple facets of integrated decision making. Indiana Journal of Global Legal Studies, 247-285.

xii. Emery, C., (2012) A three-dimensional model of corporate performance. Academy of Management Review.

xiii. Fioravante, P (2010) Corporate Philanthropy: A strategic marketing Consideration. The Journal of Applied Business and Economics. Thunder Bay: Oct. 2010. Vol. II, Iss.3; pg.91, 6 pgs.

xiv. Frame, G., (2005). The impact of public scrutiny on corporate philanthropy. Journal of Business Ethics, 69(3), 217-236.

xv. Friedman, M. (1970). The social responsibility of business is to increase its profits. The New York Times Magazine, 32-33, 122, 124, 126.

xvi. Fontaine, C., (2013), 'Sustainable Livelihoods: The Poor's Reconciliation of Environment and Development', Chapter 7 in Paul Ekins and Manfred Max-Neef eds., Real-Life Economics: Understanding Wealth Creation, New York: Routledge.

xvii. Harris, M., Timothy, A., Kevin P., Gallagher, P and Neva R. Goodwin eds. (2001), A Survey of Sustainable Development: Social and Economic Dimensions, Washington, D.C.: Island Press.

xviii. Holling, C.S. (1973), 'Resilience and Stability of Ecological Systems', Annual Review of Ecological Systems41-24.

xix. Holling, C.S. (1992), 'An Ecologist View of the Malthusian Conflict', in Kerstin Lindahl-Kiessling and Hans Landberg eds., Population, Economic Development, and the Environment, New York and Oxford: Oxford University Press. 
xx. Holmberg, J. ed. (1992), Making Development Sustainable: Redefining Institutions, Policy, and Economics, Washington, D.C.: Island Press.

xxi. Inskeep, E. (1998) Guide for local authorities on developing sustainable tourism, World Tourism Organization. International Journal of Contemporary Hospitality Management, vol. 8, no. 5, pp. 15-19.

xxii. Jayne, K., (2004) 'Creating and implementing a model for sustainable development in tourism enterprises', Journal of Cleaner Production, vol. 13, pp. 151-164.

xxiii. Katrinli, A., Gunay, G. \&Biresselioglu, M. (2011) The Business Review, Cambridge Hollywood: Summer 2011. Vol. 17, Iss. 1; pg. 164, 8 pgs

xxiv. Konrad, A.; Steurer, R; Langer, M.; Martinuzzi, A. (2006). Empirical Findings on Business-Society Relations in Europe. Journal of Business Ethics, 63: 57-67.

xxv. Kotler, P., (2005). Principles of Marketing (2nded.). London: Prentice Hall

xxvi. Kotler, P. and Lee, E. (2005) Strategic Marketing for Nonprofit Organizations, 4th edition, Englewood Cliffs, NJ: Prentice-Hall, Inc.

xxvii. Kotler, P., (2016) Principles of Marketing. (2rd edition.). Sydney: Pearson Education Australia.

xxviii. Mahajan, P., (2011). Corporate Social Responsibility: A new wave of corporate governance.

xxix. McWilliams, A; Siegel, D. (2001). Corporate Social Responsibility: A theory of the firm's perspective. Academy of Management Review,vol 26: 117-127.

xxx. Mintu, Lozada and Polonsky, Environmental Issues in the Curricula of International Business, the green imperative, Haworth Press Inc., 1993 xi-xiv.

xxxi. Polonsky M., Jan-Benedict, E., Steenkamp, D., Marnik G. and Mintu A, (1997)'The future of Environmental marketing: Food for Thought' Environmental marketing strategies, practice, theory and research Haworth1997 pg. 389-391.

xxxii. Reed, D. ed. (1997), Structural Adjustment, the Environment and Sustainable Development, London: Earth scan Publications.

xxxiii. Scherr, J. (1997), 'People and Environment: What is the Relationship between Exploitation of Natural Resources and Population Growth in the South?' Forum for Development Studies (1), 33-58.

xxxiv. Smith, P. (1998). Marketing Communications, Second Edition, Kogan Page, London, 1993, p.188

xxxv. Stoddart, H. (2011). A Pocket guide to sustainable development governance. Stakeholder Forum.

xxxvi. Werther J.\& Chandler, O. (2006). The sustainable business challenge, A briefing for tomorrows business leaders, Greenleaf publishing, pg. 137-158, 191.

xxxvii. World Watch, (2000).'Earth day 2000; A 30-year Report Card' Vol.13, No.2 March/April 2000, pg.10-13. 